\title{
Lack of Sphingosine Causes Susceptibility to Pulmonary Staphylococcus Aureus Infections in Cystic Fibrosis
}

\author{
Shaghayegh Tavakoli Tabazavareh ${ }^{\mathrm{a}} \quad$ Aaron Seitz $^{\mathrm{b}}$ Peter Jernigan ${ }^{\mathrm{a}, \mathrm{b}} \quad$ Carolin Sehla $^{\mathrm{a}}$ \\ Simone Keitsch ${ }^{a}$ Stephan Lang ${ }^{c}$ Barbara C. Kahld Michael Edwards ${ }^{b}$ \\ Heike Grassmé Erich Gulbins $^{\mathrm{a}, \mathrm{b}}$ Katrin Anne Becker ${ }^{\mathrm{a}}$ \\ aDepartment of Molecular Biology, University Hospital Essen, University of Duisburg-Essen, Essen, \\ Germany; ${ }^{b}$ Department of Surgery, University of Cincinnati, Cincinnati, USA; 'Department of \\ Otorhinolaryngology, University Hospital Essen, Essen, Germany; Institute of Medical Microbiology, \\ University Hospital Münster, Münster, Germany
}

\section{Key Words}

Sphingosine $\cdot$ Ceramide $\cdot$ Staphylococcus aureus $・$ Pneumonia $\cdot$ Cystic fibrosis

\begin{abstract}
Background: Pulmonary Staphylococcus aureus (S. aureus) infections occur early in a high percentage of cystic fibrosis (CF) patients and it is believed that these infections facilitate further colonization of CF lungs with Pseudomonas aeruginosa ( $P$. aeruginosa). Previous studies demonstrated a marked reduction of sphingosine in tracheal and bronchial epithelial cells in CF compared to wild type mice, while ceramide is massively increased in CF mice. Methods: We investigated the effect of C18-sphingosine and C16-ceramide on S. aureus in vitro. Based on our results we performed pulmonary infections with $S$. aureus and tested the influence of sphingosine inhalation. Results: In vitro incubation of S. aureus with C18-sphingosine rapidly killed S. aureus, while C16-ceramide did not affect bacterial survival, but abrogated the effect of C18-sphingosine when applied together. The in vivo infection experiments revealed a high susceptibility of CF mice to pulmonary infection with S. aureus. Inhalation of C18-sphingosine rescued CF mice from pulmonary infections with different clinical $S$. aureus isolates, including a methicillin-resistant S. aureus (MRSA) strain. Conclusions: Our data indicate that the imbalance between ceramide and sphingosine in the CF respiratory tract prevents killing of S. aureus and causes the high susceptibility of CF mice to pulmonary S. aureus infections.
\end{abstract}




\section{Cellular Physiology Cell Physiol Biochem 2016;38:2094-2102 and Biochemistry Published online: May 17, $2016 \quad \begin{aligned} & \text { DOI: 10.1159/000445567 } 2016 \text { The Author(s). Published by S. Karger AG, Basel } \\ & \text { www.karger.com/cpb }\end{aligned}$ \\ Tavakoli Tabazavareh et al.: Sphingosine Prevents S. Aureus Infections in CF}

\section{Introduction}

Cystic fibrosis (CF) is caused by mutations of the cystic fibrosis transmembrane conductance regulator (CFTR) and is one of the most common autosomal recessive disorders in Western populations [1-3]. The genetic defect results in a multisystem disease, but chronic pulmonary inflammations and infections are the major cause of morbidity and are responsible for the reduced life expectancy of CF patients. The most common microorganisms in CF lungs are Staphylococcus aureus (S. aureus), Pseudomonas aeruginosa (P. aeruginosa), Haemophilus influenzae (H. influenzae) and Stenotrophomonas maltophilia [4]. The cause of the high susceptibility of CF patients to pulmonary infections is still incompletely understood.

Several studies in recent years demonstrated that sphingolipids play a crucial role in the pathogenesis of CF [5-11]. We previously showed an age-dependent accumulation of ceramide in the respiratory tract of uninfected Cftr-deficient mice, which mediates inflammation and susceptibility to pulmonary P. aeruginosa infections [5, 12]. Analysis of human samples confirmed the accumulation of ceramide in the respiratory tract of CF patients, including bronchial epithelial cells, submucosal glands, and alveolar type II epithelial cells [5-10]. Further, we have previously demonstrated a marked reduction of sphingosine, a metabolite of ceramide, in the respiratory tract of CF mice compared to wild type (WT) mice [13]. Ceramide accumulation and deficiency of sphingosine in CF airways is due to an imbalance between ceramide formation and degradation, caused by alkalization of intracellular secretory lysosomes and small surface domains of CF cells [5, 13-15]. Deficiency of $\mathrm{Cftr}$ may result in a reduced flow of $\mathrm{Cl}$-ions into lysosomes and possibly small domains on the cell surface preventing accumulation of $\mathrm{H}^{+}$and thereby resulting in alkalization of secretory lysosomes and surface domains in CF epithelial cells. This increase of $\mathrm{pH}$ almost completely prevents activity of acid ceramidase (responsible for ceramide hydrolysis), while the activity of the acid sphingomyelinase (responsible for ceramide formation) is only partly affected $[5,16]$. The imbalance in the activities of these two enzymes ultimately results in ceramide accumulation and sphingosine deficiency in CF cells [13].

Our studies have demonstrated that the presence of sphingosine in the airway epithelium is required for the host defense against pulmonary P. aeruginosa infections [13]. This is consistent with previous studies that demonstrated antimicrobial activity of sphingosine in the skin and in the oral mucosa [17-19].

Here we investigated the bactericidal effect of sphingosine and its role in pulmonary infections with $S$. aureus. We analyzed the effect of sphingosine, ceramide or a combination of both lipids on bacterial survival. We confirmed these in vitro data in vivo by inhalation of C18-sphingosine prior to pulmonary infection with different $S$. aureus strains. The data show that the presence of sphingosine is critical for the pulmonary defense against $S$. aureus as its reconstitution in CF mice protects these mice from pulmonary infection with $S$. aureus.

\section{Material and methods}

\section{Mice}

We employed two CF mouse strains: Cftr ${ }^{\text {tm1Unc }}-$ Tg $^{\text {FABP-CFTR }}$ (abbreviated $C f t r^{K O}$ ) and B6.129P2(CF/3)Cftr ${ }^{\mathrm{TgH} \text { (nеоim)HgU }}$ (abbreviated $C f \mathrm{fr}^{\mathrm{MHH}}$ ) generated as previously described [20-25]. All mice were bred and housed in a special pathogen free facility at the University of Duisburg-Essen, Germany. Their hygienic status was repeatedly tested against a panel of common murine pathogens according to the 2002 recommendations of the Federation of European Laboratory Animal Science Associations (FELASA). Mice were handled according to protocols approved by the University of Duisburg-Essen Animal Care Committee as per international guidelines (Az 84-02.04.2013.A282). All mice were used after 16 weeks of age to ensure full manifestation of CF disease.

Human samples

Polyps were surgically removed from the paranasal sinuses of patients with and without CF after having given informed consent. Surgical interventions were performed at the Department of Otorhinolaryngology, 


\section{Cellular Physiology Cell Physiol Biochem 2016;38:2094-2102 and Biochemistry Published online: May 17, $2016 \quad \begin{aligned} & \text { DOI: 10.1159/000445567 } \\ & \begin{array}{l}\text { c } 2016 \text { The Author(s). Published by S. Karger AG, Basel } \\ \text { ww.karger.com/cpb }\end{array}\end{aligned}$ \\ Tavakoli Tabazavareh et al.: Sphingosine Prevents S. Aureus Infections in CF}

University Hospital Essen. The polyps were fixed with 4\% paraformaldehyde (PFA, Sigma-Aldrich, Steinheim, Germany) in phosphate buffered saline (PBS, $137 \mathrm{mM} \mathrm{NaCl}, 2.7 \mathrm{mM} \mathrm{KCl}, 7 \mathrm{mM} \mathrm{CaCl}{ }_{2}, 0.8 \mathrm{mM} \mathrm{MgSO}_{4}, 1.4 \mathrm{mM}$ $\mathrm{KH}_{2} \mathrm{PO}_{4}$, and $6.5 \mathrm{mM} \mathrm{Na}_{2} \mathrm{HPO}_{4}, \mathrm{pH} 7.3$ ) for $36 \mathrm{hrs}$ and then embedded in paraffin.

\section{Bacteria}

In vivo and in vitro infections were performed with the clinical $S$. aureus strain E25 isolated from sputum of a patient with CF [26], a septic strain (septic) isolated from a patient with sepsis [27] and a clinical MRSA strain USA 300 isolated from a burn patient (Cincinnati).

All $S$. aureus strains were grown on fresh trypticase soy agar (TSA) plates supplemented with 5\% sheep blood (Becton Dickinson Biosciences, Heidelberg, Germany). The plates were incubated for 16 hrs at $37^{\circ} \mathrm{C}$. The next day, bacteria were transferred into $40 \mathrm{~mL}$ of pre-warmed, sterile trypticase soy broth (Becton Dickinson Biosciences). The optical density was adjusted to 0.25 (at $550 \mathrm{~nm}$ ), and the bacteria were grown for $1 \mathrm{hr}$ at $37^{\circ} \mathrm{C}$ with shaking at $125 \mathrm{rpm}$ to obtain bacteria in the early logarithmic phase. Bacteria were centrifuged (10 $\mathrm{min}, 870 \mathrm{~g}$ ), the supernatant removed, and bacteria were resuspended and diluted in pre-warmed airway surface liquid (ASL) buffer (consisting of $10 \mathrm{mM} \mathrm{HEPES,} 63 \mathrm{mM} \mathrm{NaCl}, 2.4 \mathrm{mM} \mathrm{KCl}, 1.2$ $\mathrm{mM} \mathrm{CaCl}_{2}, 1.9 \mathrm{mM} \mathrm{MgSO}_{4}, \mathrm{pH} 6.6,6.8$, or 7.2, respectively) [28] or in Hepes/saline (H/S, consisting of $20 \mathrm{mM}$ HEPES, $132 \mathrm{mM} \mathrm{NaCl}, 5 \mathrm{mM} \mathrm{KCl}, 1 \mathrm{mM} \mathrm{CaCl}_{2}, 0.7 \mathrm{mM} \mathrm{MgCl}_{2}, 0.8 \mathrm{mM} \mathrm{MgSO}_{4}$, pH 7.4).

Treatment of bacteria in vitro

To determine the effect of ceramide and sphingosine on S. aureus strain E25 in vitro, the bacteria were grown as above and diluted to $5 \times 10^{3}$ colony forming units (CFU) in ASL buffer. Stock solutions of sphingolipids (C18-sphingosine, C18-sphingosine 1-phosphate and C16-ceramide, all from Avanti Polar Lipids, Inc., Alabama, USA) in Octyl $\beta$-D-glucopyranoside solution (OGP, Sigma-Aldrich, Steinheim, Germany) were prepared by sonication (to gain micelles) and added to the bacteria. The buffer or OGP alone served as controls. Bacteria were incubated with the different sphingolipids for $1 \mathrm{hr}$ at $37^{\circ} \mathrm{C}$, following which aliquots of the bacterial suspensions were plated on LB agar plates, incubated overnight at $37^{\circ} \mathrm{C}$ and colonies were counted.

\section{Infection of mice}

Mice were anesthetized with ether for 10-15 seconds and $2.5 \times 10^{8} \mathrm{CFU}$ of the $S$. aureus strain E25, or $1 \times 10^{8} \mathrm{CFU}$ of the $S$. aureus strains septic or MRSA in $20 \mu \mathrm{H} / \mathrm{S}$ were carefully injected into the nose with a 30-gauge 1-mL syringe. The needle was covered with a tightly fitting, smooth plastic tube so that nasal injuries were avoided.

Mice were infected once with $S$. aureus strains septic and MRSA. The infection with the strain E25 was repeated after $24 \mathrm{hrs}$. Animals were sacrificed by cervical dislocation $4 \mathrm{hrs}$ after the final infection, and the lung was removed under sterile conditions, homogenized, lysed in $5 \mathrm{mg} / \mathrm{mL}$ saponin for $10 \mathrm{~min}$ at $37^{\circ} \mathrm{C}$, washed in RPMI-1640 supplemented with 10 mM HEPES, resuspended in the same buffer and aliquots were plated on TSA plates for overnight growth.

\section{Mouse inhalation}

Inhalation was performed 30-40 min prior to infection using a PARI Boy SX nebulizer (PARI GmbH, Starnberg, Germany) as previously described [13]. Mice inhaled $800 \mu \mathrm{L}$ of $0.9 \% \mathrm{NaCl}$ containing C18sphingosine (125 $\mu \mathrm{M}$; dissolved in 0.6\% OGP) or the corresponding amount of OGP as a control. C18sphingosine and OGP were ultrasound treated in a sonication bath for 10 min directly before use.

\section{Immunohistochemical analysis of sphingosine}

Animals were sacrificed and lungs or trachea were removed immediately, fixed with PFA, embedded in paraffin and sections stained with anti-sphingosine antibody (clone NHSPH, Alfresa Pharma Corporation, Japan) as previously described [13]; human samples were digested 20 min with Pepsin Digest All (Invitrogen Life Technologies, Darmstadt, Germany), mouse lung and trachea for $30 \mathrm{~min}$. The specificity of the antisphingosine antibody used has been previously described [13].

\section{Statistics}

Data are means \pm SD. Statistical significance was evaluated using the GraphPad Prism 5 program performing ANOVA with Bonferroni as post-hoc-test. Values less than 0.05 were considered statistically significant. 


\section{Cellular Physiology Cell Physiol Biochem 2016;38:2094-2102 \begin{tabular}{ll|l} 
and Biochemistry & $\begin{array}{l}\text { DOI: 10.1159/000445567 } \\
\text { Published online: May 17, } 2016\end{array}$ & $\begin{array}{l}\text { (c) 2016 The Author(s). Published by S. Karger AG, Basel } \\
\text { www.karger.com/cpb }\end{array}$
\end{tabular}

\section{Results and Discussion}

\section{Sphingosine in the respiratory tract}

Immunohistochemical stainings using a previously characterized [13] sphingosinespecific antibody revealed an abundant expression of sphingosine in epithelial cells of airways. Sphingosine was highly expressed in apical membranes and cilia of human nasal epithelial cells obtained from healthy individuals or tracheal and bronchial epithelial cells from WT mice, while it was almost absent or greatly reduced at the luminal surface of nasal epithelial cells of CF patients or tracheal and bronchial cells of two different CF mouse strains (Fig. 1A,B). Cftr ${ }^{M H H}$ mice, which have a residual expression of $C f t r$, showed marginal sphingosine quantities in the trachea and lung, while sphingosine was almost undetectable in $C f t r^{\mathrm{KO}}$ mice completely lacking Cftr (Fig. 1B).

\section{Sphingosine versus ceramide effects on S. aureus strain E25}

In addition to reduced sphingosine levels in the respiratory tract (this work and [13]), human patients and mice with CF also show increased ceramide levels in nasal, tracheal and bronchial CF epithelial cells $[5-8,10]$. We aimed to determine the effect of ceramide and sphingosine on the $S$. aureus strain E25, because this strain is a clinical isolate from sputum of a CF patient. Mimicking the milieu of the respiratory tract, we incubated the $S$. aureus strain with C18-sphingosine, C16-ceramide or a combination of both lipids in an airway surface liquid (ASL) buffer. This buffer contains a similar electrolyte composition as the ASL [28].

Since the pH of the ASL differs in healthy (pH 6.8-7.2) and CF (pH 6.6) individuals [29$33]$, the ASL buffer was tested at different $\mathrm{pH}$ values. ASL buffer alone showed a bactericidal

Fig. 1. Immunohistochemical analysis of sphingosine in human nasal epithelial cells and murine airways. Paraffin sections of the paranasal sinus mucosa, obtained from patients with or without CF (A), and of trachea and lung, obtained from WT and $\mathrm{CF}$ mice (B), were probed with a Cy3coupled anti-sphingosine antibody and analyzed by confocal microscopy. The size scale at the bottom right is valid for the entire raw. Shown are representative images $(n \geq 5)$.

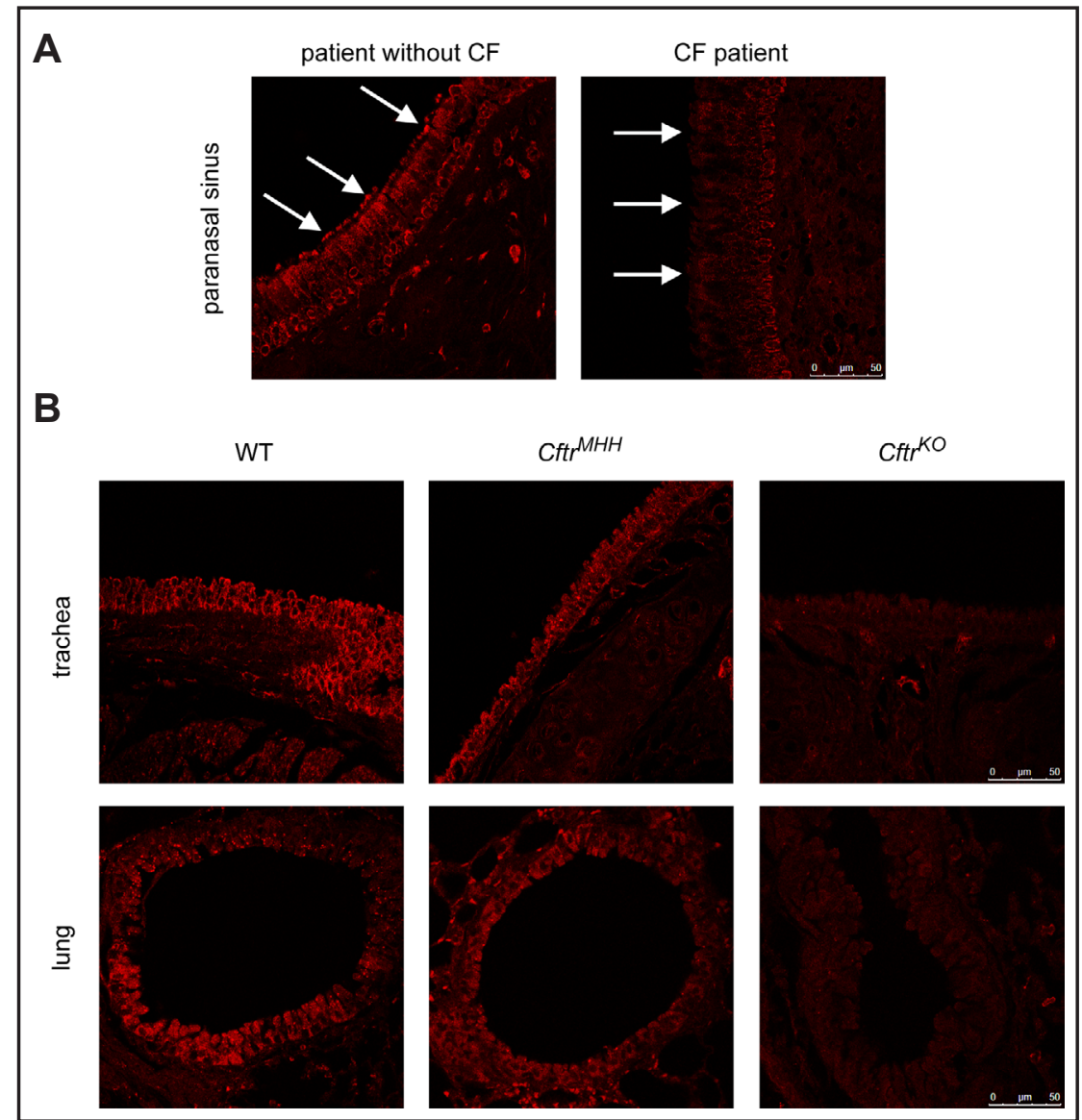


Fig. 2. Incubation of $S$. aureus E25 with different sphingolipids in airway surface liquid. S. aureus E25 was incubated with sphingolipid micelles diluted in airway surface liquid (ASL) buffer at one of three different $\mathrm{pH}$ values $(6.6,6.8,7.2)$. After $1 \mathrm{hr}$ incubation $10 \%$ of the suspension was cultured on agar plates for determination of CFU the next day. Survival of $S$. aureus was calculated as percentage of the initial amount of bacteria. Bacterial survival after incubation with ASL buffer alone or the solvent OGP served as controls. (SPH: sphingosine; CER: ceramide; S1P: sphingosine 1-phosphate). Shown are the mean $\pm \mathrm{SD}, \mathrm{n} \geq 3,{ }^{*} \mathrm{p}<0.05$, ANOVA and Bonferroni post-hoc test.
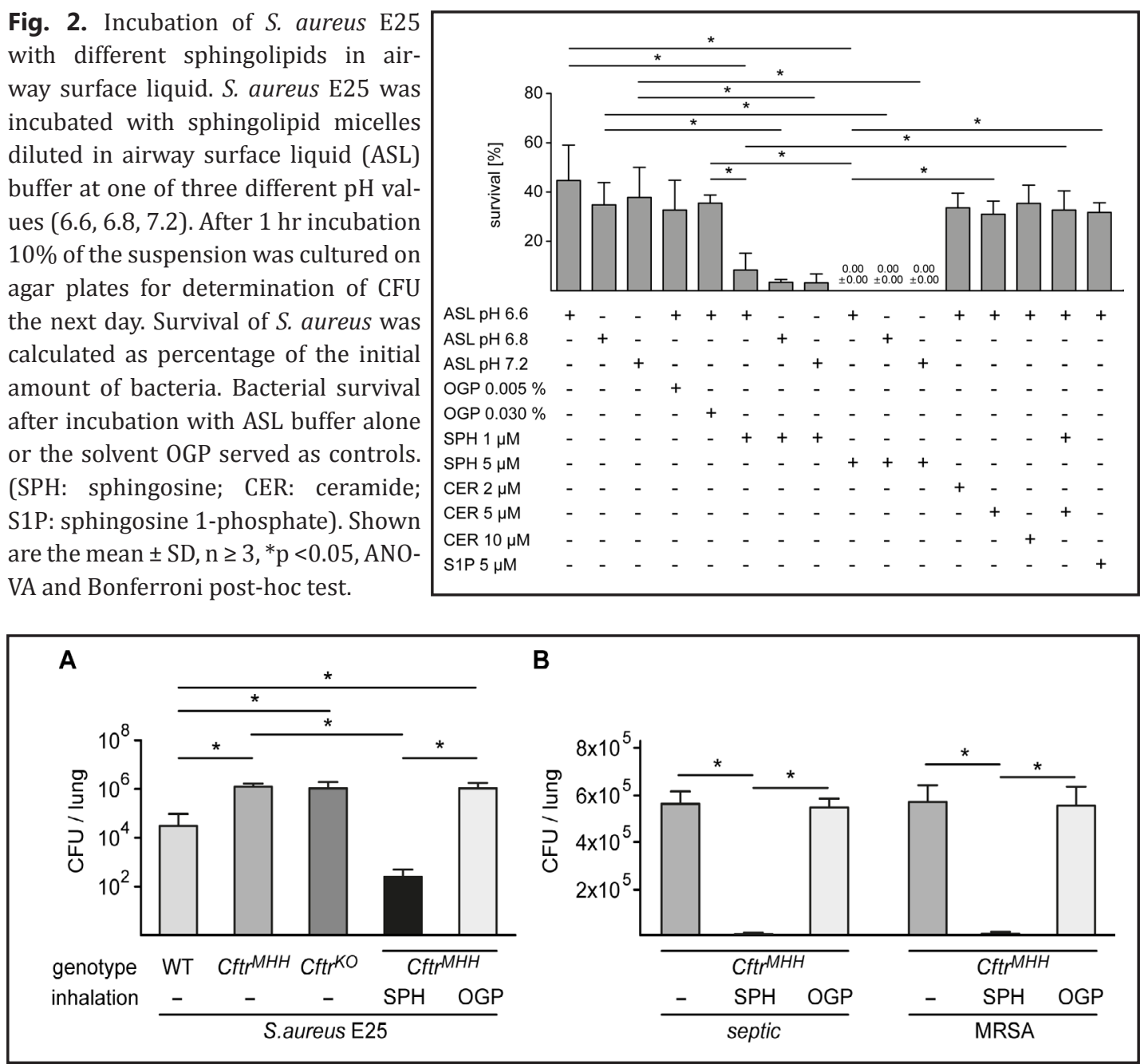

Fig. 3. C18-sphingosine inhalation prevents pulmonary $S$. aureus infections in CF mice. WT and CF mice were infected intranasally with $2.5 \times 10^{8} \mathrm{CFU}$ of $S$. aureus E25 twice within 24 hrs (A) or once with $1 \times 10^{8}$ CFU of the S. aureus strain septic or an MRSA strain (B). The bacterial load of lungs was determined 4 hrs after the final infection. Mice inhaled C18-sphingosine $(125 \mu \mathrm{M})$ or the solvent OGP $(0.6 \%) 30-40$ minutes prior to infection. Shown are the mean \pm SD, each WT $\mathrm{n}=11 ; C f \operatorname{tr}^{M H H} \mathrm{n}=6 ; C_{f t r}{ }^{K O} \mathrm{n}=5$, inhaled $C f \operatorname{tr}^{M H H}$ mice with $\mathrm{n}=4$ for C18-sphingosine and $\mathrm{n}=5$ for OGP in $\mathrm{A}, \mathrm{n}=6$ for each $C f \operatorname{tr}^{\mathrm{MHH}}$ group in $\mathrm{B} ;{ }^{*} \mathrm{p}<0.05$, ANOVA and Bonferroni post-hoc test.

effect, irrespective of the $\mathrm{pH}$ value (Fig. 2). The solvent OGP had no additional effect compared to buffer alone. C16-ceramide at different concentrations did not change the survival rate of the $S$. aureus strain E25. In contrast, addition of C18-sphingosine for $1 \mathrm{hr}$ significantly reduced bacterial survival: $1 \mu \mathrm{M}$ micellar C18-sphingosine killed more than $90 \%$ of the bacteria and $5 \mu \mathrm{M}$ C18-sphingosine killed all S. aureus (Fig. 2). The antibacterial activity of micellar C18-sphingosine was independent of the $\mathrm{pH}$ value of ASL buffer between 6.6 and 7.2. C16-ceramide and C18-sphingosine 1-phosphate had no bactericidal effect (Fig. 2). Notably, the combination of sphingosine and ceramide (Fig. 2, second bar from right) did not kill $S$. aureus indicating that the ratio between ceramide and sphingosine determines killing of $S$. aureus by sphingosine in membranes.

It is unknown how ceramide reduces or even abolishes the bactericidal effect of sphingosine. Further, the exact mechanism of the antibacterial activity of sphingoid bases is still unclear. Electron microscopy of sphingosine-treated $S$. aureus revealed multiple lesions of cell wall, membrane evaginations, loss of ribosomes and leakage of cellular debris trough 
Fig. 4. The ratio between ceramide and sphingosine determines the bactericidal defense of the upper airways. The respiratory tract of CF is characterized by sphingosine deficiency and ceramide accumulation. This imbalance prevents effective pathogen clearance and causes a high susceptibility to pulmonary infections with $S$. aureus. Inhalation of C18-sphingosine corrects this high susceptibility of CF mice.

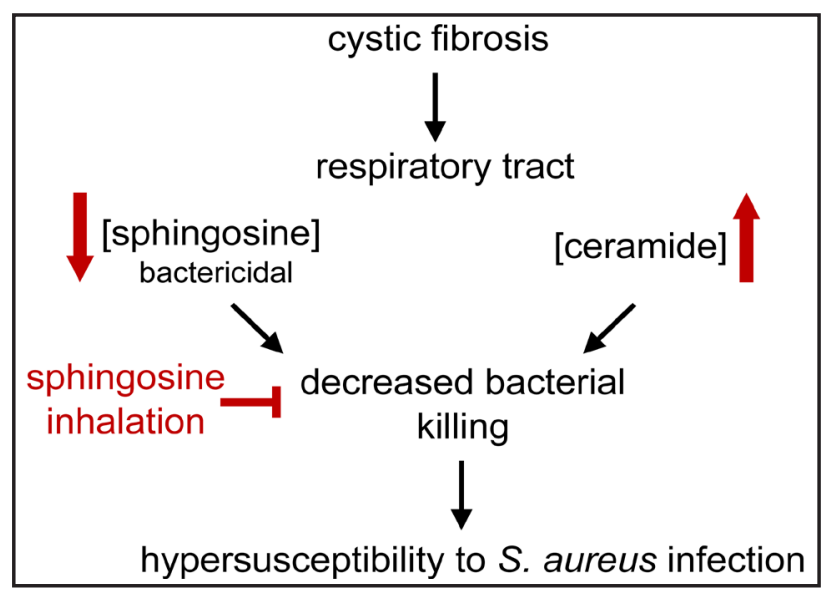

gaps in the wall [34, 35]. In addition Fischer and colleagues (2013) demonstrated extensive uptake of sphingoid bases by bacteria and detected internal inclusion bodies, likely associated with cell death, but it is unknown whether such an uptake of sphingosine by the pathogen occurs in vivo after contact of the pathogen with mammalian membranes [35].

Sphingosine might act in bacterial membranes after transfer from the mammalian to the bacterial membrane and this transfer process might be inhibited by ceramide. Alternatively, sphingosine might act after aggregation to small domains in the mammalian membrane. These domains may interfere with the bacterial membrane or surface proteins to kill the pathogen. Higher concentrations of ceramide might interfere with the formation of these domains and thus block the bactericidal effect of sphingosine. Finally, sphingosine may bind to bacterial proteins to kill the pathogen and ceramide might either interfere with that binding or actively prevent the function of these proteins in the bacteria.

It is suspected that the positive charge of the nitrogen atom of sphingoid bases is relevant for the antibacterial effect of sphingosine $[13,17,35]$. The following observations support this hypothesis: First, an increase of the $\mathrm{pH}$ value $(\mathrm{pH}>8)$ and consequent deprotonation of the sphingoid base lead to loss of antibacterial activity [17]. Second, structural comparison revealed that longer and more positively charged sphingoid bases are more effective than shorter, negatively charged ones [13]. However, within the relevant $\mathrm{pH}$ range for airway surface liquid, we did not detect a significant impact of the $\mathrm{pH}$ on the anti-bactericidal effect of sphingosine.

Sphingosine inhalation prevents in vivo infections with several S. aureus strains, including MRSA

Infection of CF mice with the CF S. aureus strain E25 revealed a very high susceptibility of CF mice to $S$. aureus compared to WT mice (Fig. 3A). The two CF mouse strains showed high numbers of $S$. aureus in the lung, while WT rapidly cleared the infection. To analyze the relevance of the antibacterial activity of C18-sphingosine for pulmonary infections in vivo, Cftr ${ }^{\mathrm{MHH}}$ mice were treated with C18-sphingosine via inhalation 30-40 min prior to infection. C18-sphingosine inhalation protected CF mice from infection with $S$. aureus strain E25 (Fig. 3A).

In addition to more toxic strains of $S$. aureus, infections with resistant $S$. aureus strains are a serious clinical problem [36]. Therefore, we tested whether sphingosine also kills a septic and a clinical MRSA isolate. Infection of CF mice with these two strains resulted in severe pneumonia (Fig. 3B). Inhalation of sphingosine by CF mice prior to the nasal infection prevented the development of pneumonia and killed the pathogen in both cases (Fig. 3B).

Here we show for the first time that sphingosine in airways acts against $S$. aureus and prevents infections with this pathogen. The antibacterial activity of this sphingoid base is not limited to $S$. aureus and it has been demonstrated against various Gram-positive and Gram-negative bacteria $[13,17,19]$. Specifically, sphingosine demonstrates antibacterial 


\section{Cellular Physiology Cell Physiol Biochem 2016;38:2094-2102 and Biochemistry Published online: May 17, $2016 \quad$\begin{tabular}{l|l} 
DOI: 10.1159/00445567 2016 The Author(s). Published by S. Karger AG, Basel \\
www.karger.com/cpb
\end{tabular} \\ Tavakoli Tabazavareh et al.: Sphingosine Prevents S. Aureus Infections in CF}

activity against numerous CF-relevant pathogens including $P$. aeruginosa, $H$. influenzae, Acinetobacter baumannii, Moraxella catarrhalis and Burkholderia cepacia [13].

Consistent with previous findings, CF mice in the present study show a much higher infection susceptibility to pulmonary $S$. aureus infections than WT mice [37]. This susceptibility to $S$. aureus correlates with decreased expression of sphingosine in the respiratory epithelium. These data suggest that the absence of sphingosine in the airways of CF patients and mice results in the high susceptibility to pulmonary $S$. aureus infections. Inhalation of C18-sphingosine corrects these defects, reconstitutes sphingosine to a level similar to that in healthy controls, and confers resistance to $S$. aureus strains including a MRSA strain. Moreover, we provide evidence that the ratio between ceramide and sphingosine in the airways determines the bactericidal effects (Fig. 4). Thus, therapies that combine a normalization of ceramide in CF airways [38, 39] with the application of sphingosine might be most effective to prevent or treat an existing bacterial infection in these patients. Preventing early manifestation of chronic pulmonary S. aureus infections by inhaling sphingosine during the early childhood would be a great chance to minimize the risk for later infections with P. aeruginosa of CF patients.

\section{Acknowledgements}

The studies were supported by DFG grant GU 335/30-1.

\section{Disclosure Statement}

The authors have nothing to disclose.

\section{References}

1 Rommens JM, Iannuzzi MC, Kerem B, Drumm ML, Melmer G, Dean M, Rozmahel R, Cole JL, Kennedy D, Hidaka N, Zsiga M, Buchwald M, Riordan JR, Tsui LC, Collins FS: Identification of the cystic fibrosis gene: Chromosome walking and jumping. Science 1989;245:1059-1065.

2 Riordan JR, Rommens JM, Kerem B, Alon N, Rozmahel R, Grzelczak Z, Zielenski J, Lok S, Plavsic N, Chou JL, Drumm ML, Iannuzzi MC, Collins FS, Tsui LC: Identification of the cystic fibrosis gene: Cloning and characterization of complementary DNA. Science 1989;245:1066-1073.

3 Kerem B, Rommens JM, Buchanan JA, Markiewicz D, Cox TK, Chakravarti A, Buchwald M, Tsui LC: Identification of the cystic fibrosis gene: Genetic analysis. Science 1989;245:1073-1080.

4 American Cystic Fibrosis Foundation: Patient registry annual data report 2013, 2014,

5 Teichgräber V, Ulrich M, Endlich N, Riethmüller J, Wilker B, De Oliveira-Munding CC, van Heeckeren AM, Barr ML, von Kürthy G, Schmid KW, Weller M, Tümmler B, Lang F, Grassmé H, Döring G, Gulbins E: Ceramide accumulation mediates inflammation, cell death and infection susceptibility in cystic fibrosis. Nat Med 2008;14:382-391.

6 Brodlie M, McKean MC, Johnson GE, Gray J, Fisher AJ, Corris PA, Lordan JL, Ward C: Ceramide is increased in the lower airway epithelium of people with advanced cystic fibrosis lung disease. Am J Respir Crit Care Med 2010;182:369-375.

7 Ulrich M, Worlitzsch D, Viglio S, Siegmann N, Iadarola P, Shute JK, Geiser M, Pier GB, Friedel G, Barr ML, Schuster A, Meyer KC, Ratjen F, Bjarnsholt T, Gulbins E, Döring G: Alveolar inflammation in cystic fibrosis. J Cyst Fibros 2010;9:217-227.

8 Bodas M, Min T, Mazur S, Vij N: Critical modifier role of membrane-cystic fibrosis transmembrane conductance regulator-dependent ceramide signaling in lung injury and emphysema. J Immunol 2011;186:602613. 


\section{Cellular Physiology Cell Physiol Biochem 2016;38:2094-2102 \begin{tabular}{l|l} 
and Biochemistry 10.1159/000445567 & $\begin{array}{l}\text { D) } 2016 \text { The Author(s). Published by S. Karger AG, Basel } \\
\text { www.karger.com/cpb }\end{array}$
\end{tabular} \\ Tavakoli Tabazavareh et al.: Sphingosine Prevents S. Aureus Infections in CF}

9 Becker KA, Riethmüller J, Lüth A, Döring G, Kleuser B, Gulbins E: Acid sphingomyelinase inhibitors normalize pulmonary ceramide and inflammation in cystic fibrosis. Am J Respir Cell Mol Biol 2010;42:716-724.

10 Becker KA, Tümmler B, Gulbins E, Grassmé H: Accumulation of ceramide in the trachea and intestine of cystic fibrosis mice causes inflammation and cell death. Biochem Biophys Res Commun 2010;403:368-374.

11 Becker KA, Grassmé H, Zhang Y, Gulbins E: Ceramide in Pseudomonas aeruginosa infections and cystic fibrosis. Cell Physiol Biochem 2010;26:57-66

12 Grassmé H, Carpinteiro A, Edwards MJ, Gulbins E, Becker KA: Regulation of the inflammasome by ceramide in cystic fibrosis lungs. Cell Physiol Biochem 2014;34:45-55

13 Pewzner-Jung Y, Tavakoli Tabazavareh S, Grassmé H, Becker KA, Japtok L, Steinmann J, Joseph T, Lang S, Tümmler B, Schuchman EH, Lentsch AB, Kleuser B, Edwards MJ, Futerman AH, Gulbins E: Sphingoid long chain bases prevent lung infection by pseudomonas aeruginosa. EMBO Mol Med 2014;6:1205-1214.

14 Barasch J, Kiss B, Prince A, Saiman L, Gruenert D, al-Awqati Q: Defective acidification of intracellular organelles in cystic fibrosis. Nature 1991;352:70-73.

15 Di A, Brown ME, Deriy LV, Li C, Szeto FL, Chen Y, Huang P, Tong J, Naren AP, Bindokas V, Palfrey HC, Nelson DJ: Cftr regulates phagosome acidification in macrophages and alters bactericidal activity. Nat Cell Biol 2006;8:933-944.

16 Okino N, He X, Gatt S, Sandhoff K, Ito M, Schuchman EH: The reverse activity of human acid ceramidase. J Biol Chem 2003;278:29948-29953.

17 Bibel DJ, Aly R, Shinefield HR: Antimicrobial activity of sphingosines. J Invest Dermatol 1992;98:269-273.

18 Arikawa J, Ishibashi M, Kawashima M, Takagi Y, Ichikawa Y, Imokawa G: Decreased levels of sphingosine, a natural antimicrobial agent, may be associated with vulnerability of the stratum corneum from patients with atopic dermatitis to colonization by staphylococcus aureus. J Invest Dermatol 2002;119:433-439.

19 Fischer CL, Drake DR, Dawson DV, Blanchette DR, Brogden KA, Wertz PW: Antibacterial activity of sphingoid bases and fatty acids against gram-positive and gram-negative bacteria. Antimicrob Agents Chemother 2012;56:1157-1161.

20 Snouwaert JN, Brigman KK, Latour AM, Malouf NN, Boucher RC, Smithies O, Koller BH: An animal model for cystic fibrosis made by gene targeting. Science 1992;257:1083-1088.

21 Zhou L, Dey CR, Wert SE, DuVall MD, Frizzell RA, Whitsett JA: Correction of lethal intestinal defect in a mouse model of cystic fibrosis by human cftr. Science 1994;266:1705-1708.

22 Dorin JR, Dickinson P, Alton EW, Smith SN, Geddes DM, Stevenson BJ, Kimber WL, Fleming S, Clarke AR, Hooper ML, Anderson L, Beddington RS, Porteous DJ: Cystic fibrosis in the mouse by targeted insertional mutagenesis. Nature 1992;359:211-215.

23 Dorin JR, Stevenson BJ, Fleming S, Alton EW, Dickinson P, Porteous DJ: Long-term survival of the exon 10 insertional cystic fibrosis mutant mouse is a consequence of low level residual wild-type cftr gene expression. Mamm Genome 1994;5:465-472.

24 Charizopoulou N, Jansen S, Dorsch M, Stanke F, Dorin JR, Hedrich HJ, Tümmler B: Instability of the insertional mutation in cftrtgh(neoim)hgu cystic fibrosis mouse model. BMC Genet 2004;5:6.

25 Charizopoulou N, Wilke M, Dorsch M, Bot A, Jorna H, Jansen S, Stanke F, Hedrich HJ, de Jonge HR, Tümmler B: Spontaneous rescue from cystic fibrosis in a mouse model. BMC Genet 2006; 7:18.

26 Hirschhausen N, Block D, Bianconi I, Bragonzi A, Birtel J, Lee JC, Dubbers A, Kuster P, Kahl J, Peters G, Kahl BC: Extended staphylococcus aureus persistence in cystic fibrosis is associated with bacterial adaptation. Int J Med Microbiol 2013;303:685-692.

27 Henry BD, Neill DR, Becker KA, Gore S, Bricio-Moreno L, Ziobro R, Edwards MJ, Mühlemann K, Steinmann J, Kleuser B, Japtok L, Luginbühl M, Wolfmeier H, Scherag A, Gulbins E, Kadioglu A, Draeger A, Babiychuk EB: Engineered liposomes sequester bacterial exotoxins and protect from severe invasive infections in mice. Nat Biotechnol 2015;33:81-88.

28 Baconnais S, Tirouvanziam R, Zahm JM, de Bentzmann S, Peault B, Balossier G, Puchelle E: Ion composition and rheology of airway liquid from cystic fibrosis fetal tracheal xenografts. Am J Respir Cell Mol Biol 1999;20:605-611.

29 Kyle H, Ward JP, Widdicombe JG: Control of ph of airway surface liquid of the ferret trachea in vitro. J Appl Physiol (1985) 1990;68:135-140.

30 Jayaraman S, Song Y, Verkman AS: Airway surface liquid ph in well-differentiated airway epithelial cell cultures and mouse trachea. Am J Physiol Cell Physiol 2001;281:C1504-1511. 


\section{Cellular Physiology Cell Physiol Biochem 2016;38:2094-2102 \begin{tabular}{l|l} 
DOI: 10.1159/000445567 & $\begin{array}{l}\text { O 2016 The Author(s). Published by S. Karger AG, Basel } \\
\text { www.karger.com/cpb }\end{array}$
\end{tabular} \\ Tavakoli Tabazavareh et al.: Sphingosine Prevents S. Aureus Infections in CF}

31 Fischer H, Widdicombe JH, Illek B: Acid secretion and proton conductance in human airway epithelium. Am J Physiol Cell Physiol 2002;282:C736-743.

32 Song Y, Salinas D, Nielson DW, Verkman AS: Hyperacidity of secreted fluid from submucosal glands in early cystic fibrosis. Am J Physiol Cell Physiol 2006;290:C741-749.

33 Pezzulo AA, Tang XX, Hoegger MJ, Alaiwa MH, Ramachandran S, Moninger TO, Karp PH, Wohlford-Lenane CL, Haagsman HP, van Eijk M, Banfi B, Horswill AR, Stoltz DA, McCray PB, Jr., Welsh MJ, Zabner J: Reduced airway surface ph impairs bacterial killing in the porcine cystic fibrosis lung. Nature 2012;487:109-113.

34 Bibel DJ, Aly R, Shah S, Shinefield HR: Sphingosines: Antimicrobial barriers of the skin. Acta Derm Venereol 1993;73:407-411.

35 Fischer CL, Walters KS, Drake DR, Blanchette DR, Dawson DV, Brogden KA, Wertz PW: Sphingoid bases are taken up by escherichia coli and staphylococcus aureus and induce ultrastructural damage. Skin Pharmacol Physiol 2013;26:36-44.

36 Lo DK, Hurley MN, Mühlebach MS, Smyth AR: Interventions for the eradication of meticillin-resistant staphylococcus aureus (mrsa) in people with cystic fibrosis. Cochrane Database Syst Rev 2015;2:CD009650.

37 Davidson DJ, Dorin JR, McLachlan G, Ranaldi V, Lamb D, Doherty C, Govan J, Porteous DJ: Lung disease in the cystic fibrosis mouse exposed to bacterial pathogens. Nat Genet 1995;9:351-357.

38 Riethmüller J Anthonysamy J, Serra E, Schwab M, Döring G, Gulbins E: Therapeutic Efficacy and Safety of Amitriptyline in Patients with Cystic Fibrosis. Cell Phys Biochem 2009;24:65-72.

39 Nährlich L, Mainz JG, Adams C, Engel C, Herrmann G, Icheva V, Lauer J, Deppisch C, Wirth A, Unger K, Graepler-Mainka U, Hector A, Heyder S, Stern M, Döring G, Gulbins E, Riethmüller J: Therapy of CF-Patients with Amitriptyline and Placebo - a Randomised, Double-Blind, Placebo-Controlled Phase IIb Multicenter, Cohort-Study. Cell Phys Biochem 2013;31:505-512. 